\title{
KASHMIR: THE MYTH OF ISOLATION
}

\author{
Brijish Jahan \\ Assistant professor in History, Government Degree College, Tangmarg, Baramulla, Jammu and Kashmir, India. \\ Email: brijishjahan@gmail.com \\ Supervisor: Prof. (Dr) Parvez Ahmad, Department of History, University of Kashmir, Srinagar, Jammu and \\ Kashmir, India. Email: drparvezku@gmail.com.
}

\begin{abstract}
Situated on the northern extremity of India, the state of Jammu and Kashmir occupied a very important and strategical position in the Political map of the British Indian Empire. Its boundaries extend from the northern outskirts of the vast plains of Punjab to the point where the borders of independent powers of Russia and China almost touch British India. The independent kingdom of Afghanistan meets it on the North West. The valley of Kashmir seems to occupy a position of the very highest importance with reference to the safety of British India, for it may be looked upon as an entrenched camp situated on the flank of any force attempting the invasion of the empire from the west, while it lies directly on the road of an enemy advancing by the routes from Badakshan, Kashgar and Yarkand.
\end{abstract}

Key words: Topography, Mountainous, Passes, Political-Relations, Empire, Trade-routes, Trade- Enterpot, Economy, Scientific frontier.

The Jammu and Kashmir state popularly termed as "Jewel Decked Crown of India," almost Centrally situated on the Map of Asia, was of strategic significance not only for the then British India but for all other immemorial, when trade routes linking Central Asia with Southern Asia passed through this land. It was this geographical contiguity of Kashmir with Central Asia and Tibet on which Pandit Jawahar Lal Nehru the Prime Minister of India has said, that Kashmir while part of India was infact 'Heart of Asia', "For countless ages" Great Caravans have passed from India right up to Central Asia through the state.

\section{NATURAL DESCRIPTION}

The description of the natural boundaries and area of Kashmir as given by the Arabic and Persian writers are generally vague in nature. When they speak of Kashmir they include the valley as well as the regions around it. Al-Biruni's description pertains to the valley the conceived of it as lying on a plateau \{higher ground\} with the low lying areas of India to the south and Central Asia to the north. The north and east part of the country belonged to the Turks of Khotan and Tibet. The distance, he says, from the peak of Boteshwar to Kashmir through Tibet is nearly 300 \{farsakhs\} about 900 miles. Sharaf- al- din Yazdi describes the valley as lying in a longitudinal position endorsed on all sides by mountain; the southern range in the direction of Delhi; the northern towards Badakshan and Khurasan, the western towards the country of the Afghan and the eastern terminating in the outlying distinct of Tibet. Al-Biruni, and sharafal-din were naturally describing a changed political map.

Mirza Haider Dughlat places Kashmir to the west of Tibet. The plain \{julga\} of Kashmir, according to him, extended from the Bakani quarter which means "between the south and the east" towards the Rikan Bain fon the North-West\}. He gives a fairly correct longitudinal position of the valley, namely, that it stretched from South-East to North West.

The Mughal historians over give a more accurate description of the boundaries as follows: on the east are the region (now called Pakistan) and the river Chenab; on the south east, Banihal and the Jammu mountains, on the 
north east, Great Tibet; on the west Pakli and the Kishenganga; on the South- West, the Gakhar country, and on the North West, little Tibet. It is encompassed on all sides by Himalayan ranges.

In a mountainous state over fifty percent of which is/was almost barren uninhabited, roads play a vital role in the transportation of people and goods. None of the natural features of Kashmir geography have had a more direct bearing on the history of the country than the great mountain barriers that surround it. They may hence rightly claim our first consideration.

The importance of the mountains as the county's great protecting wall has at all times been duly recognized both by inhabitants and foreign observers. Since an early period Kashmiris have been won't to pride themselves on their country's safety from foreign invasion, a feeling justified only by the strength of these natural defense. We find it alluded to by Kalhana who speaks of Kashmir on unconquerable by the forces of soldiers, and of the protection afforded by its mountain walls. The feeling is very clearly reflected in all foreign records of the country. We have already seen what special notice is taken by Hieun Tsang and Qu-kong of the mountains enclosing the kingdom and the difficulty of the passes due stress on the inaccessible character of the mountains. Al-biruni does the same, and shows us besides the anxious care taken in olden days to maintain this natural strength of the country by keeping strict watch over the passes.

\section{Political Relations}

The above mentioned natural description of the valley have had helped in development of her political and economic ties with South and Central Asia from remote times. This view is supported by Some fragmentary records in Sanskrit of the Later Vedic Period(1000B.C-600B.C) that the political relations between the two regions go back to the Pre-historic past with regard to the Achaemenian and Greek invasions of India, it showed that Kashmir formed a part of Gandhara, the Eastern region of Afghanistan. Though Rajtarangini has given no detailed and authentic information about the conditions prevailing in Kashmir, and the adjoining regions of North Western India during the Pre-Asokan period, but According to Kalhana, Kashmir formed a part of Mauryan Empire (322B.C-185B.C) whose dominions extended Eastward to Bengal and Westward to Hindukush. He mentioned that the King Asoka in 3nd century B.C has built the city of Srinagar which up to sixth century A.D was the capital of the valley.

Henceforth, the relations of Kashmir with Central Asia remained intact till a Chieftain of the Kushan clan, Kanishka succeeded in 78 A.D and had extended his empire from Central Asia to the borders of Bengal, conquered North-Western India as far as Banaras. The expansionist policy of creating large empires was also followed by the native rulers. We see Lalitaditya, ruler of Kashmir from 724-761 A.D, brought Kashmir in close contact with the rest of India, as Lalitaditya gave wide extent to his dominions. The Punjab, Kanuj, Tibet, Badakshan, and other territories are said to have been brought into subjection by him. But with the decline of Karkotas or Hindu rule, Kashmir boundaries was shrunk, until the weak kings were content to rule over the precincts of the valley alone and sometimes less. According to Kalhana, the Kabul valley, Rajouri and Poonch, Kangra and Jammu, Kishtwar and Ladakh had, one by one, thrown off their allegiance to the kings of Kashmir, the extent of the area of Kashmir more or less remained confined to valley proper.

\section{ECONOMiC RELATIONS}

These political changes would have come with the economic benefits too. Unfortunately, we do not have figures to show how this inclusion with the big empires had boosted Kashmir economy but we see during this period Kashmir had assumed considerable significance as an enterpot of transit trade owing to its geographical contiguities with Central Asia and its linkage with the "Old Silk Route." The passes leading to the Central Asian plains through the Kabul valley also formed important lines of communication with Kashmir. The road from the valley followed closely the course of the Jehlum and after crossing the Urusha (Hazara) District, joined the caravan route from India. It was over this route, which makes the "Western Gate of Kashmir" that Hieun Tsiang 
and Ou'kung travelled to reach the valley. It would not be out of place to mention that the trade routes which passed through Kashmir territory via Srinagar-Leh-Yarkand- Kashgar-Kokand were preferred by traders in as much as these were devoid of political turmoil and banditry as compared to the equally famous routes via Bukhara-Afghanistan-Punjab. It is to be pointed out that all these channels of trade routes were important for conducting trade with Central Asia until the discovery of Sea routes. As these were the only links of joining Kashmir to the rest of the world especially to these areas. These routes acted as lifeline for the Kashmiri's trade with outside world.

No doubt the External trade of Kashmir was largely carried through the aforementioned trade route network, but, owing to various political and other reasons the road from Srinagar to distant Yarkand and Lhasa was often blocked by snow resulting in the severance of the life-lines of commerce though temporarily. However, the demand of Kashmiri products was so strong and intimate that the merchants took roundabout and difficult tracks to reach Tibet or Central Asia.

It is important to mention here that since the nature (composition) of Kashmir's External trade was largely determined by volume-value ratio (as these were snow bound areas so products which were less in weight, but high in demand were preferred by merchants to carry on these routes) of the commodities, therefore, Kashmir shawl became a preferable item of this trade. Needless to say, that the Kashmiri shawl becoming the fashion of the day at the Mughal court, the demand for Kashmiri shawl increased manifold. It was perhaps the high profitability of the shawl business that the traders took a circuitous route to import raw wool for this industry from Tibet. In this regard Bernier, writes, since the eruption of Shajhan into little Tibet",

"The king of the latter place not only interdicted the passage of the caravans, but forbade any person from Kashmir to enter his dominion". From Kashmir, traders went to Patna, thence to Nepal and finally to Lhasa.

During the Sultanate Period Zainu'l Abidin (1420A.D-1470 A.D) had encouraged the production of shawls, silks, paper, glass, and other crafts, but no details are available regarding their manufacturing and quantity. Pandit Anand Kaul a Kashmiri historian writes:

"Zainu'-l-Abidin turned Kashmir into a smiling garden of industry inculcating in the hearts of the people conception of labour and also implanting in their minds, the germ of real progress. He introduced correct measures and weights...... promoted commercial morality, integrity and industrial righteousness; it was through these virtues that the Kashmiris successfully carried on their shawl and other trade worth crores of rupees annually with distant corners of the globe at a period when Kashmir was an isolated country and communications with the outside world were very difficult."

It was during the Sultanate period in Kashmir political boundaries have reached to distant places viz. India and Afghanistan for victories: Sultan Zainul- Abidin had re-conquered the Punjab and Western Tibet. The Sultan for the promotion of trade and commerce constructed buildings a huge Serai, or resting place, for travelers from Central Asia in valley. He is said to have sent ambassadors with adequate presents to the kings of Khorasan, Turkistan, Turkey, Egypt and Delhi for the promotion of trade.

We see during the Mughal era (1586A.D-1719A.D), there was close commercial and political intercourse between the Mughal Empire and Kashmir. It was only for a brief interval that the trade activities on Central Asian highway were affected in 1682-83A.D and their endeavors in Ladakh. The region in the alien hands had posed a threat to the Mughal authority and also damaged the woolen industry of Kashmir. At the culmination of the war between the Tibetians and the Mughals, a 'Tripartite Treaty' was concluded and the frontiers demarcated once for all. This treaty not only created favorable conditions for the improvement of trade with Central Asia, but generally it gave fillip to the revival of Kashmir's trade with other neighbouring region. During the Mughal period, Kashmir boundaries were again extended beyond Tibet, Ladakh, and Kishtawar as they were brought under nominal suzerainty of Mughals. 
On the eve of the Mughal occupation of Kashmir, shawl industry had not only been extensively established but the industry had attained a high degree of perfection. According to Mughal chronicler, Abul Fazl, there were two hundred factories for making shawls and were exported to various countries of the world. The shawls of Kashmir were given the name of Param Naram by Emperor Akbar. Jahangir says that they are so excellent that 'there is no need to praise them (Hajat Ba Tariff Naist). He also made shawls one of favorite component of dress. The delicate texture, softness and durability had made Kashmiri shawls unrivalled in the whole world making them extensive article of trade. To quote Abul Fazl 'the Kashmiri shawls are exported to ever clime'.

Even during the Afghan Rule (1753-1819 A.D) in Kashmir, Kashmir continued to remain an important trade enter pot between the Punjab and Central Asia. When the Afghans annexed Kashmir, the shawl industry received a great stimulus as they showed much liking for the shawls. The Afghan Monarchs who were fond of this stuff long before the subjugation of Kashmir directed their Governors to pay a portion of the state revenue in shawl goods. They sent a large quantity of the fabric to Afghanistan where it was re-exported to various countries at fabulous prices. The chief contribution of the Afghans was that they developed shawl trade with Europe which had a great economic significance for this industry.

With a few exceptions of invading forces these routes mainly had commercial importance, a carrier of goods, men, movements and ideas till $19^{\text {th }}$ century. With the dawn of $19^{\text {th }}$ century witnessed the emergence of Kashmir as a vital frontier of British India. The fame of its scenic beauty and rich cultural heritage had already spread to distant corners of the world, but with the rapid advance of the British Indian empire to the North; the amazing growth of power and expansion of Tsarist Russia in Asia; and the extension of Chinese borders to Sinkiang, Kashmir acquired a unique strategic position as the place where the three Great Empires meet, soon it became a centre of activity of various foreign agents engaged in collecting the information and its Geography, Administrative setup and Defence. With the advance of the century, the course of Kashmir history was increasingly affected by the political situation prevailing on both the sides of the Karakorum, as well as by the relations existing between the British Indian Government and the Sikhs (Maharaja Ranjit Singh) and his successors.

The first realization of Kashmir's strategic importance dawned on the British Government after the conclusion of the Treaty of Friendship with Maharaja Ranjit Singh at Amritsar in 1809A.D, by which they agreed to abstain from any interference with the territories of the Maharaja's North of Sutlej, while he agreed respect the territories and subjects of the Chiefs South of the river. The Maharaja Ranjit Singh honorably observed his engagements and abandoning his dream of Cis-Sutluj supremacy, turned his attention to the expulsion of the Afghans from Northern districts of the Punjab, and the reduction of Multan, Kashmir and Derajat. In 1819 he wrested out valley out of the hands of the Afghans.

Meanwhile, the British who out of fear of the Russian advance into Central Asia and Persia, were getting interested in the Northern region of Ranjit Singh dominions, began costing their covetous eyes on the beautiful valley. Hence we find a number of British nationals penetrating into Kashmir and adjoining areas to extend sphere of influence there. Some of them like Moorcroft fomented the trouble Ranjit Singh in Ladakh and other frontier regions. He actively encouraged the Raja of Ladakh to refuse payment to the Sikh Governor of Kashmir, and got an application of the Raja forwarded to the British government. From the strategic point of view, the valley of Kashmir seemed to occupy a position of the very highest importance with reference to the safety of British India, for it may be looked upon as an entrenched camp situated on the flank of any force attempting the invasion of the Empire from the West, while it lied directly on the road of an enemy advancing by the routes from Badakshan, Kashgar and Yarkand.

This shows that the real intention of the British was to cripple the Sikhs by fair or foul means. The new state was weakened to such an extent that its absorption in the British in Asia was only a matter of time. The British, who were always eager to profit by internal disorders of the Indian state, came forward and set in action their unscrupulous diplomacy which resulted in the destruction of the Sikhs and subsequently led to the annexation 
of this kingdom by British. At about the same time, they created a state of Jammu and Kashmir for Gulab Singh in (1846A.D) which was quite different from the pre-historic times. Now the state was quite large in area Jammu, Rajouri, Gilgit, Baltistan, Ladakh, Muzaffarabd etc were brought under direct control by Dogra Maharaja; they ruled Kashmir for next 100 years.

\section{CONCLUSION}

From the above discussion it becomes clear that Kashmir had developed trade relationship with Central Asia and China since times immemorial which for some time came to be dominated by the British Imperial polices particularly in the second half of the nineteenth century. However, with the Russian expansion in Central Asia and their constant rivalry with British, the trade relations between Kashmir and Central Asia, China, and other European countries, got a setback. The Imperial designs of the two competing powers left the Kashmir on adverse receiving end, as a result of the closer of its routes. Though, trade between these countries continued in different ways till 1947. However with the partition of the India in 1947A.D, Kashmir was once again caught between the two newly created powers, India and Pakistan which till now have kept Kashmir into a stagnant position, as the routes approaching to Central Asia and China had been closed.

\section{REFERENCES}

1. Albiruni-Kitab ul Hind, (ed)(Tr) by Sachau's, Edward C in English and introduction and notes by Qeyamuddin Ahmad and published by National Book Trust, India.

2. Bernier, Travels in the Mughal Empire (1656-68),1914, edited by Constable and Revised by Smith, V. A., Oxford Publications, London, p.427.

3. Bamzai, P. N. K, Kashmir and Central Asia, 1980, Light and Life publishers, New Delhi, p.23-28.

4. Ibid, From Lhasa there was a trade route to Sinning fu on the Chinese frontier, North-east to Khosai and the Charing Nor. The Lhasa trade though very remunerative was also a hazardous tiresome business." Even part from the dangers of warfare and banditry, the physical discomforts likely to be met on the road were forbidding and the distances to be traversed immense. Transport depended upon beasts of burden which were slower than ships and not necessarily safer; the horse, the mule and the ass, the one-humped camel in the South West and the Bacterian camel in colder climates, the yak and the Hainag( a cross between a bullyak and a domestic cow)." At high altitudes, carts drawn by horses, oxen and camels lost their lives on the way and many of those who landed in Lhasa preferred to settle there permanently, never to return home. And if there were some to withstand the return journey as well, they had earned enough to be able to spend the rest of their life in ease and opulence. Hence the Kashmir saying"

Yusgav lass uh zahnaav

Av ai tas nah zah wav

He who went to Lhasa (Tibet) never returned,

If he did come back then he was a rich man forever.

5. Ibid, Silk Route so named because it was mostly used by caravans who brought silk from China to Persia and to the Levantine market was firmly established. It was along this route that semi-diplomatic and commercial missions travelled from the Eastern shores of the Mediterranean across the middle east Bactria, Samarkand, and the Central Asian region to China though the Northern and Southern branches of the Silk Route trade and ideas were exchanged and transmitted. Except a few, there are no insuperable barriers to human penetration on the Southern boundary of Central Asia, marked by an almost unbroken chain of mountain ranges nearly four thousand miles long. The chain running from China to the Black Sea stands 
as a wall separating Central Asia, the Indian sub-continent and the Middle East. But the Hindukush, the Karakorum, the Paropamisus, and the Elburz which from this wall, have never restricted the movements of peoples in either direction.

6. Ibid, Kashmir had a taste of Afghan rule for a brief span of sixty six years 1753-1819, following the weakening of the authority of the Mughal Governors. When Ahmad Shah Abdali, after his victorious campaign to Delhi, was back in Lahore. Two influential leaders of Kashmir approached him for the end of Mughal rule and he gladly accepted their invitation in 1753.

7. Dughlat, Mirza Haider, Tarikh-Rashidi, (Tr) by Elias. E, Ross. D, p. 432, see also Bano. Raja, Maqbool, p. $37\{$ Historical\}.

8. Fazl, Abul, Ain-i-Akbari, 3 volumes English (Tr), Of vol, I by Blochmann and the two by H.S Jarret which were further revised by Jadu Nath Sarkar, 1974, Oriental Publisher, Delhi, pp.78-79.

9. Fillipe- De-Fillipe, An Account of his Travels (Tr), George Routlege and Sons Publication, London, 1937, p.ii, In 1714 an Italian traveler, Ippolite Desideri traversed the route and he was fascinated to find the demarcation marks around the place which placed Damchuk on the side of Kashmir and Tashgang in the Chinese Turkistan.

10. Gazetteer of Kashmir and Ladakh, rpt, 1974, New Delhi, p.434. Leh was starting point of the trade route to Tibet. It passes through Roudok at which place the Tibetan outpost was maintained. Before the Chinese annexation of Tibet there were 25 staging places called Tarjum with accommodation, sometimes houses but more generally tents, for about 200 travelers. The stage-houses were under the charge of an official who was bound to provide yaks and other beasts of burden for carrying mail; etc. Kashgar was the junction of the routes from Kashmir via, Leh. On the southern flank the routes leading up the valleys of the Yarkand River and its tributaries converged on the Karakorum pass which was the only line of communication giving access to the uppermost valley of the Indus in Ladakh area. The first important town on the Central Asian side of the Karakorum was Yarkand on a direct line between Kashgar and Leh in Kashmir. There were number of passes leading to Yarkand and Leh but generally only three were followed depending on the season as also the nature of goods carried, Yarkand and Kashgar were also approachable via Gilgit through the Hunza and Sarilkol passes. From the southern towns of Sinkiang which groups themselves along the foot of the Keunlun and once spread into plains of Lobnor and Takla Makan Desert, the road to the Oxus lay through Tashkurgan and by the passes of the Sarikol to the Great Pamirs. Bamzai, P.N.K, op.cit, pp.23-25. These mountains were also known as "Black Gravel" mountains and were of far more complicated character. From its main ridge the lofty spurs extended into Kashmir separating various tributaries of the Indus, the result being a stupendous Mountain Mass, 220 miles long, with a width on the Southern side of the watershed of 30 to 60 miles, with peaks averaging from 21,000 to 23,000 feet culminating on the west in the well known Rakaposhi mountain, north of Gilgit over 25,500 feet high, and in the mighty group of peaks round the head of the Baltoro Glacier dominated by the second highest mountain in the world "K2".

11. Hugel, Baron Charles, Travels in Kashmir and Punjab, First Published 1845, (Re-print), Gulshan Publishers, Srinagar.p.11.

12. Journal of Asiatic society of British, vol, XXVII,p.130, Three interesting gold coins of the Kushans similar to Kushan coins of Kashmir were discovered in the Rajshahi division, Bengal.

13. Koul, PanditAnand, Geography of J\&K state, (up-ed) and introduction by Bamzai, P.N.K, 1913, Calcutta, pp.61-62.

14. Moorcroft, William and Treback, George, Travels in Hindustan, vol.I,p.18-22, "in every light, therefore, whatever, of humanity of commercial benefit, or of political security, I conceived the allegiance of Ladakh voluntarily proffered and imposing no obligation from which the a slightest inconvenience could result, 
could not fail to be acceptable to my government, and I forwarded the memorial sand tender to Calcutta from natives which I am unable to appreciate and unwilling to scrutinize my conduct was wholly disapproved of , and I was severely ensured for taking unauthorized a part in political arrangements. The allegiance of Ladakh we declined, and as Ranjit Singh was informed that I had acted without the sanction of the government, that state was placed at his mercy. To have been visited with censure where I must think I merited commendation was a sufficient disappointment, but the consequences were still worse, and the difficulties and dangers which subsequently beset my progress were mainly owing to the harsh, peremptory and public manner in which credit was affixed to my proceedings but the resident of Delhi and the government of Bengal, in spite of the tremendous endeavors to restore tranquility, plenty and prosperity in Kashmir enabling his to make regular remittances to quote Mehan Singh could not remove Ranjit Singh, suspicious that he was dishonest, although in 1835, both Vigne and Hugel, who had watched his administration in Kashmir closely had on their return to Lahore, assured Ranjit Singh that Mehan Singh had established prosperity In Kashmir and he was honest.

15. Parliamentary paper, 1846, No. p.150-G(National Archives of India).

16. Parmu, R.K, History of Sikh rule in Kashmir, Department of education, Jammu and Kashmir, 1977, p.192.

17. Qazi, S.A, systematic Geography of Jammu and Kashmir, APH publishing cooperation, New Delhi, p.6.

18. Riazul Islam, Kazi. A .Kadir, Javed Husain, Central Asia History, Politics and Culture (ed), 1993, Published at Institute of Central and West Asian Studies, University of Karachi, Pakistan.pp.15-25).

19. Stein, M.A- Kalhana's Ancient Geography of Jammu and Kashmir (Tr), Verinag publishers, Mirpur Azad Kashmir, p.390.

20. Tripathi, R.S, History of Ancient India, Motilal Banarasdass Publishers, New Delhi, 2003, p.47, 82, 84.Gandhara extended on both sides of the Indus with Taxila (Rawalpindi district) and Pushkaravati (modern Charsada, Peshawar) as its principal towns and in the oldest Buddhist writings it is mentioned that there were sixteen Great Powers (Solasa Mahajanapada), which must have existed in the seventh or early eight century B.C. the fifteenth on the list is Gandhara i.e. Eastern Afghanistan, with the capital at Pushkaravati and also including Kashmir (Kashmira-Gandhara).

21.Vigne, G,T, Travels in Kashmir Ladakh and Skardu etc, London, 1942, p.74

22. Wani Mohmmad Ashraf, "Hey days of shawl industry", in Ahmad Nazir, "Craft" A magazine devoted to Arts and Crafts of Jammu and Kashmir, 16 March, 1998, Apollo Publishers, Jammu, p.30.

23. Warikoo. K, Central Asia and Kashmir, 1989, Gian Publishing House, New Delhi, p.56,

Citation: Jahan B and Ahmad P, "KASHMIR: THE MYTH OF ISOLATION". American Research Journal of History and Culture, vol 6, no. 1, 2020, pp. 1-7.

Copyright (C) 2020 Jahan B, et al, This is an open access article distributed under the Creative Commons Attribution License, which permits unrestricted use, distribution, and reproduction in any medium, provided the original work is properly cited. 